\title{
PEMODELAN 2D LAPISAN BAWAH PERMUKAAN BERDASARKAN DATA GAYA BERAT MIKRO
}

\section{(2D MODELING SUBSURFACE LAYER BASED ON MICROGRAVITY DATA)}

\author{
Supriyadi, Khumaedi, Fajar Setiawan, dan Teguh M.M \\ Universitas Negeri Semarang Indonesia \\ Sekaran Gunung Pati Semarang Jawa Tengah 50229 \\ email: supriyadi@mail.unnes.ac.id
}

\begin{abstract}
Abstrak
Penelitian ini bertujuan untuk mendeskripsikan lapisan bawah permukaan tanah berdasarkan data gaya berat. Pengukuran dilakukan pada bulan Januari 2019. Penelitian menggunakan metode geofisika yaitu metode gaya berat dan metode survei. Setelah dilakukan pengolahan kemudian data anomali gravitasi dapat diinterpretasikan dengan bantuan peta geologi. Alat yang digunakan adalah Gravimeter Scintrex CG-5 Autograv. Hasil penelitian menunjukkan bahwa struktur bawah permukaan dapat diinterpretasikan dalam empat lapisan. Lapisan pertama yaitu top soil yang termasuk formasi aluvium (Qa) dengan densitas rata-rata batuan $2.1 \mathrm{~g} / \mathrm{cm} 3$ dengan kedalaman 0-50 m. Lapisan kedua memliki densitas rata-rata batuan $2.3 \mathrm{~g} / \mathrm{cm} 3$ di kedalaman 50-120m. Lapisan ketiga memiliki densitas rata-rata batuan $2.4 \mathrm{~g} / \mathrm{cm} 3$ di kedalaman 120-195m. Penyusun batuan lapisan pertama hingga ketiga merupakan batuan sedimen seperti lempung, batupasir, dan batu serpih. Lapisan keempat adalah base yang termasuk formasi damar (Qtd) dengan densitas $2,67 \mathrm{~g} / \mathrm{cm} 3$ di kedalaman lebih dari $195 \mathrm{~m}$ dengan batuan penyusun didominasi breksi vulkanik dan tufan halus.
\end{abstract}

Kata kunci: lapisan bawah permukaan, gaya berat, pemodelan $2 D$

\begin{abstract}
This study was aimed at describing the subsurface layer based on the gravity data. The measurements were made in January 2019. The study used the geophysical method, namely the gravity method and the survey method. After being analyzed, the anomaly gravitation data then interpreted using geological maps. Gravimeter Scintrex CG-5 Autograph was used in this study. The results show that subsurface structures can be interpreted in four layers. The first layer is topsoil which includes alluvium (Qa) formation with an average rock density of $2.1 \mathrm{~g} / \mathrm{cm}^{3}$ with a depth of 0-50 m. The second layer has an average rock density of $2.3 \mathrm{~g} / \mathrm{cm}^{3}$ at a depth of 50$120 \mathrm{~m}$. The third layer has an average rock density of $2.4 \mathrm{~g} / \mathrm{cm}^{3}$ at a depth of $120-195 \mathrm{~m}$. First to third layer rock compilers are sedimentary rocks such as clay, sandstone, and shale. The fourth layer is a base that includes the formation of resin (Qtd) with a density of $2.67 \mathrm{~g} / \mathrm{cm}^{3}$ at a depth of more than $195 \mathrm{~m}$ with the constituent rocks dominated by volcanic breccias and fine tuffs.
\end{abstract}

Keywords: subsurface layer, gravity, 2D modeling

\section{PENDAHULUAN}

Kawasan Kota Lama Semarang me-

rupakan kawasan kota tua peninggalan jaman kolonial belanda yang saat ini dijadikan sebagai obyek wisata oleh Pemerintah Kota Semarang dengan luas sekitar $0,3125 \mathrm{~km}^{2}$ 
(Purwanto, 2005). Studi mengenai struktur bawah permukaan di Kota Semarang khususnya di daerah Kota Lama masih jarang dilakukan, sehingga perlu dilakukan studi penelitian mengenai struktur bawah permukaan.

Penelitian menggunakan metode geofisika yaitu metode gaya berat. Prinsip dasar dari metode ini adalah mengukur variasi medan gravitsai yang ditimbulkan karena adanya perbedaan rapat massa batuan yang berada di bawah permukaan bumi (Telford, Geldart, \& Sheriff, 1990). Dasar utama teori gaya berat adalah hukum Newton (Telford et al., 1990). Secara matematis dapat ditulis persamaan berikut.

$$
\vec{F}(\vec{r})=-G \frac{M m}{r^{2}} \hat{r}
$$

Skema gaya tarik dua benda bermassa $m$ dengan jarak $r$ ditunjukkan pada Gambar 1.

Survei yang dilakukan untuk mendapatkan informasi mengenai area survei yang terpengaruh oleh efek-efek dari berbagai sumber yang tidak diketahui di bawah permukaan terhadap perubahan variasi nilai batuan yang berada di bawah permukaan. Faktor-faktor yang mempengaruhi nilai gaya berat perlu dikoreksi untuk mengetahui efek dari sumber yang mempengaruhi perubahan nilai rapat massa atau variasi nilai batuan, di antaranya: efek kemuluran alat (drift effect), efek pasang surut (tidal effect), efek lintang, efek topografi, dan variasi rapat massa. Setelah dilakukan pengolahan kemudian data anomali gravitasi dapat diinterpretasikan dengan bantuan peta geologi seperti pada Gambar 2.

Berdasarkan nilai anomali bouger tampak bahwa sejak awal wilayah Semarang dan sekitarnya berada pada cekungan. Dalam cekungan tersebut diendapkan formasi kerek dan kalibeng serta dibatasi oleh tinggian yang berarah barat laut-tenggara ini terus berkembang sampai dengan kuarter yang ditandai oleh endapan-endapan formasi

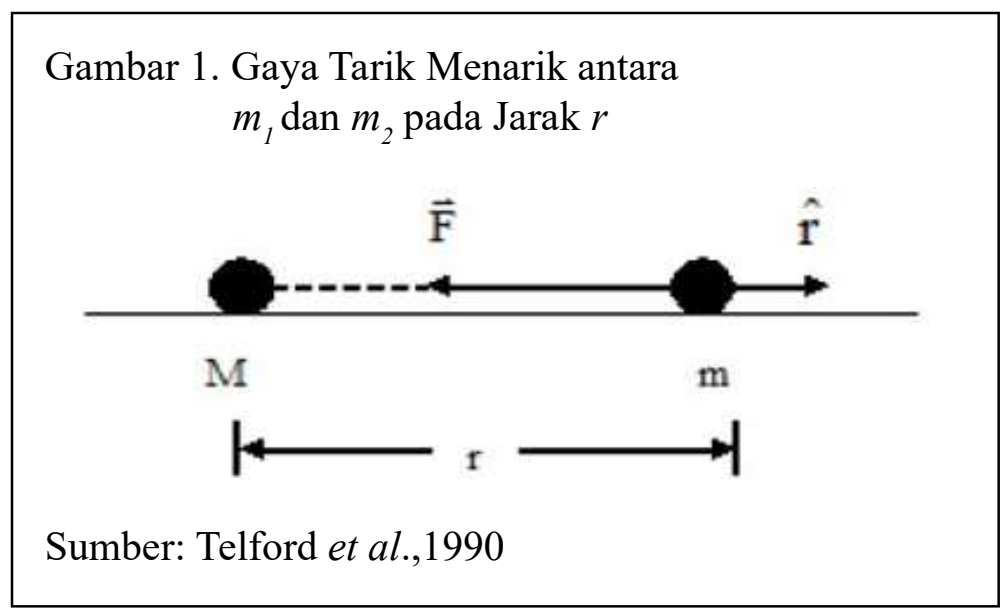




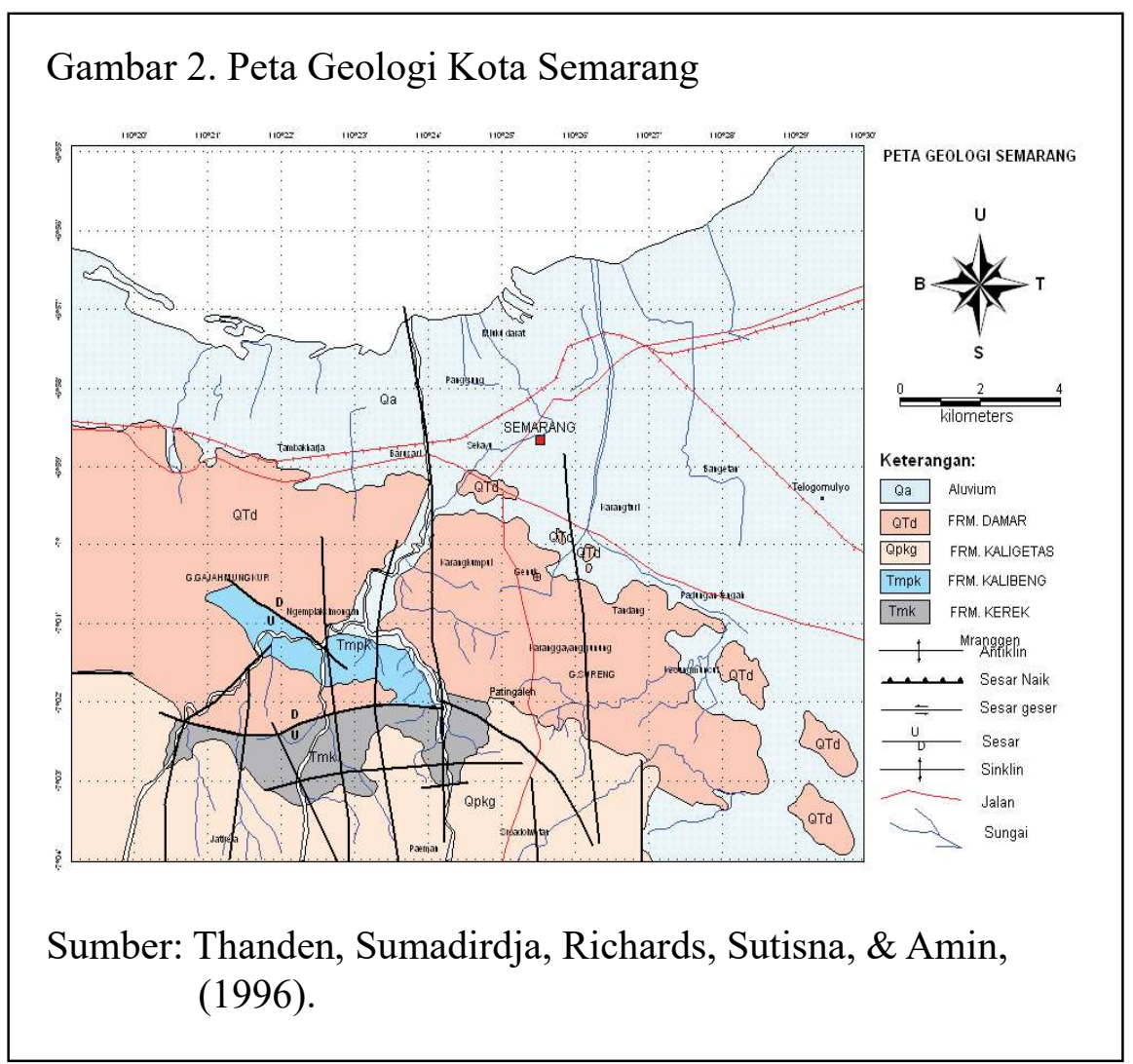

kaligetas, formasi damar, formasi jongkong dan endapan-endapan gunung api muda (Wardhana, Harjono, \& Sudaryanto, 2014).

\section{METODE PENELITIAN}

Alat yang digunakan dalam penelitian ini adalah Gravimeter Scintrex CG-5 Autograv yang digunakan untuk mengukur variasi medan gravitasi bumi. Alat ini bekerja berdasarkan hukum Newton dan hukum Hooke, yaitu beban dengan massa tertentu yang digantung oleh pegas.

Lokasi penelitian di kawasan Kota Lama, Kota Semarang yang terletak pada koordinat $110^{\circ} 25^{\prime} 30^{\prime \prime}-110^{\circ} 25^{\prime} 49^{\prime \prime}$ Bujur Timur dan 6057'52"-6058'11" Lintang
Selatan dengan luas penelitian kurang lebih $0,3125 \mathrm{~km}^{2}$. Jumlah titik pengukuran sebanyak 75 titik dengan jarak tiap titik pengukuran adalah $50 \mathrm{~m}$. Desain survei lokasi titik-titik pengukuran ditunjukkan oleh Gambar 3.

Penelitian dilakukan dengan menentukan posisi base. Kemudian menentukan titik pengukuran gaya berat dan di-plotting ke dalam Global Positioning System (GPS) sesuai dengan peta desain survei. Pengukuran dilakukan di atas permukaan titik ukur dengan alat gravimeter. Pengolahan data menggunakan bantuan software Microsoft Excel, Google Maps \& Earth, dan Geosoft Oasis Montaj 6.4.2. 


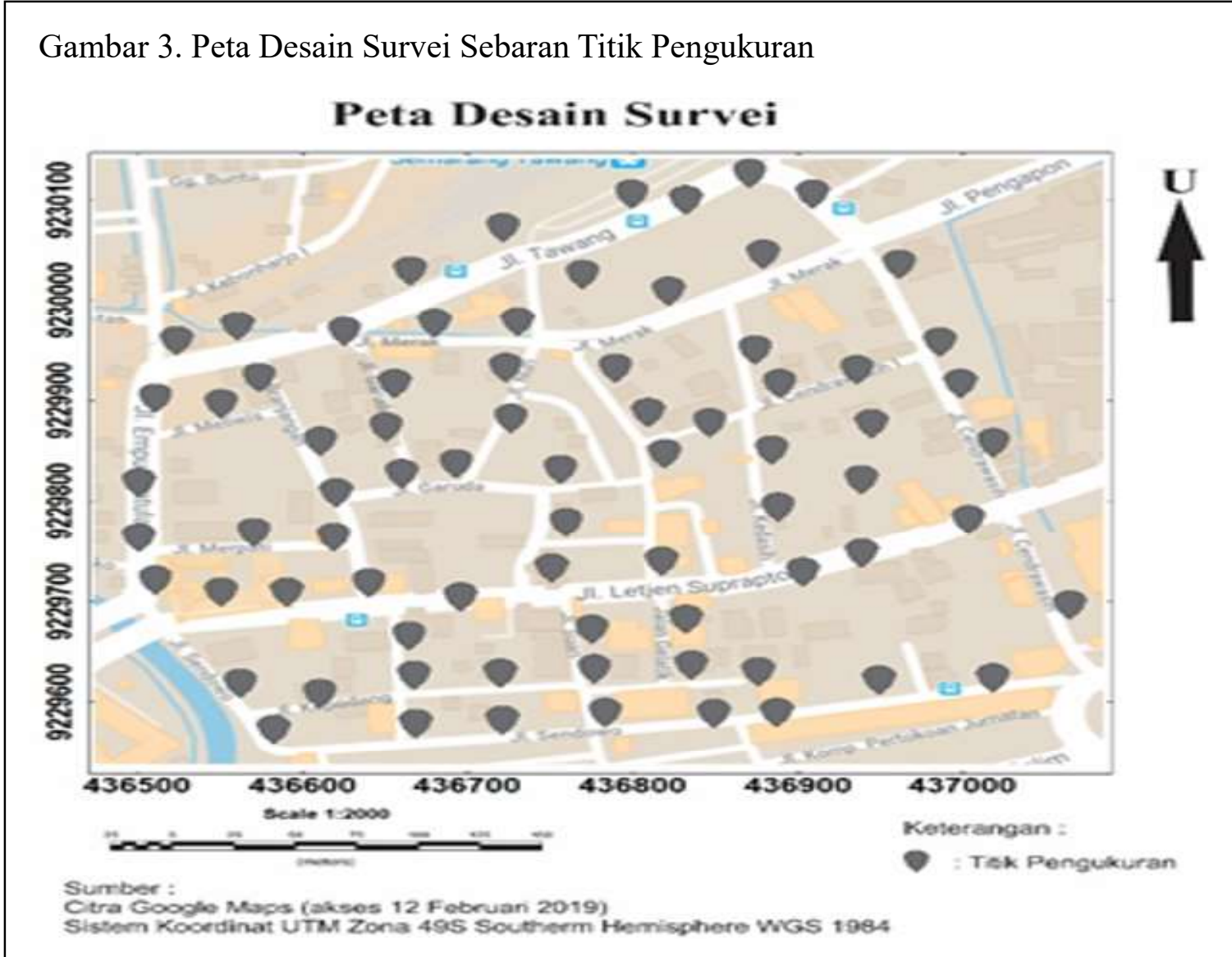

\section{HASIL DAN PEMBAHASAN}

Gaya berat observasi () adalah gaya berat yang di baca gravimeter di suatu titik pengukuran yang telah terkoreksi apungan (drift) dan pasang surut. Gaya berat observasi berbanding terbalik dengan topografi bila memiliki nilai yang tinggi maka menunjukkan topografi yang rendah sebaliknya bila memiliki nilai yang rendah maka menunjukkan topografi yang tinggi.

Untuk mendapatkan hasil anomali bouguer lengkap (CBA) dilakukan pengolahan data lapangan dengan menghitung gaya berat normal (teoritis) dan melakukan koreksi-koreksi. Dalam penelitian ini nilai densitas rata-rata batuan yang dihitung menggunakan metode parasnis adalah 2,68 $\mathrm{g} / \mathrm{cm}^{3}$. Nilai anomali bouguer lengkap adalah nilai total dari anomali yang disebabkan oleh pengaruh rapat massa batuan dari pusat inti bumi sampai ke permukaan bumi yang kemudian dapat dipisahkan menjadi anomali regional dan anomali residual (Karunianto, Haryanto, Hikmatullah, \& Laesanpura 2017). Hasil pengolahan data menjadi peta anomali bouguer lengkap dapat dilihat pada Gambar 4. 


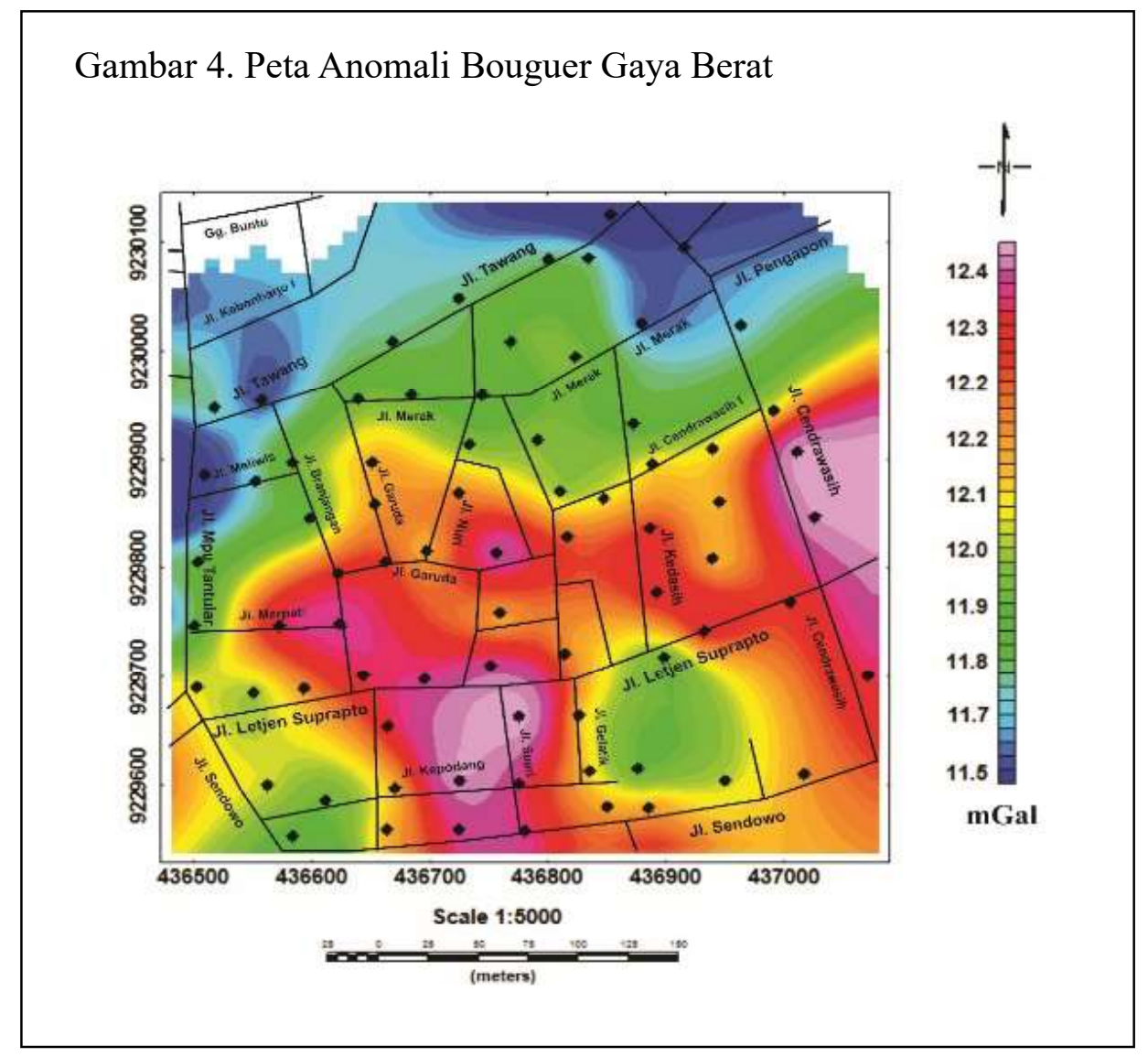

Gambar 4 menunjukkan bagian utara Jalan Tawang menunjukkan nilai anomali yang rendah berkisar 11,5-11,7 mGal dengan gradasi warna biru hingga biru muda. Bagian yang menunjukkan nilai anomali yang tinggi berada di sekitar Jalan Kepodang dan Jalan Suari yang memliki nilai antara 12,3-12,4 mGal dengan gradasi warna merah hingga merah muda. Sebagian besar kawasan Kota Lama memiliki nilai anomali dengan rentang antara 11,7-12,3 mGal yang berada di bagian tengah dengan gradasi warna merah, kuning, dan hijau. Perbedaan nilai anomali yang merepresentasikan perbedaan rapat massa batuan di daerah penelitian yang dapat mengidentifikasikan setiap lokasi memiliki material yang berbeda dengan daerah yang berada di sekitarnya.

Pemodelan struktur bawah permuka-an dapat dilakukan dengan menganalisis peta anomali bouguer setelah dipisahkan dengan metode moving average menjadi anomali regional dan residual. Pemodelan dilakukan dengan tujuan untuk mengidentifikasi struktur bawah permukaan daerah penelitian di Kota Lama. Pemodelan yang dibuat merupakan penampang 2D dari dua lintasan atau slice dari peta anomali residual. Lintasan atau slice pada peta anomali residual ditunjukkan pada Gambar 5. 


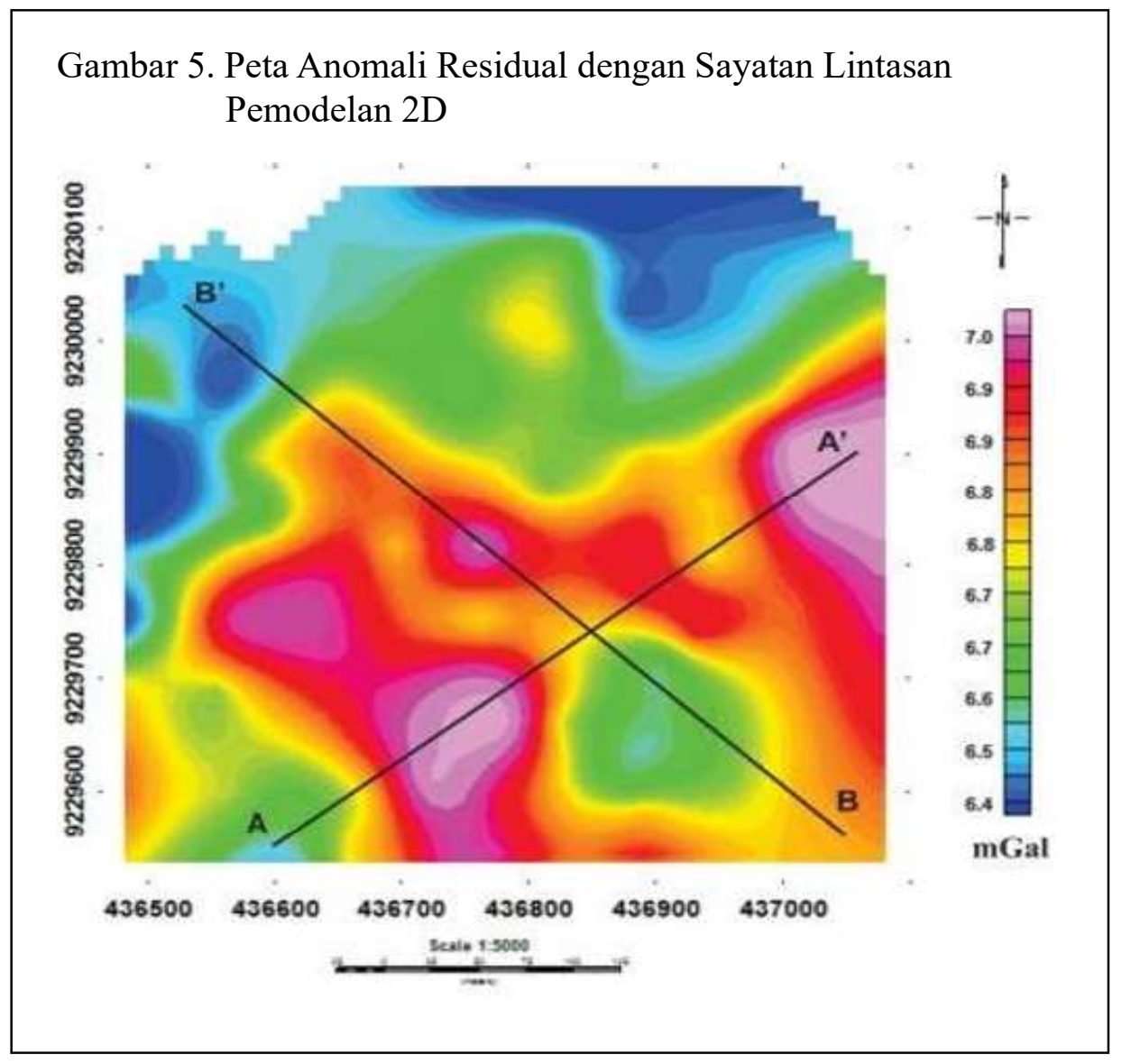

Supriyadi, Khumaedi, dan Hidayatullah (2018) menjelaskan bahwa struktur bawah permukaan Kawasan Kota Lama terbentuk dari sedimentasi delta, top soil, lumpur, dan basement. Hasil pemodelan 2 dimensi lintasan (A-A') untuk mengidentifikasi struktur bawah permukaan diinterprestasikan pada Gambar 6.

Berdasarkan Gambar 6 dapat diinterpretasikan struktur bawah permukaan Kota Lama pada sayatan lintasan A-A' menunjukkan empat lapisan. Lapisan dasar berupa base dengan kedalaman lebih dari $195 \mathrm{~m}$ dan densitas rata-rata batuan $2,68 \mathrm{~g} /$ cm3 yang merupakan bagian dari formasi damar (Qtd) berumur kuarter yang menutupi sebagian besar wilayah semarang utara. Batuan penyusun lapisan base berupa breksi vulkanik, konglomerat, dan batu pasir tufan yang ditutupi oleh endapan aluvial. Lapisan pertama, kedua, dan ketiga merupakan bagian dari formasi aluvium (Qa). Lapisan pertama merupakan top soil yang memiliki kedalaman 0-55 $\mathrm{m}$ dan densitas rata-rata batuan 2,11 $\mathrm{g} / \mathrm{cm} 3$ dengan batuan penyusun berupa campuran dari tanah urug, kerikil, pasir, lempung, dan lumpur. Lapisan kedua berada pada kedalaman 55-120 m dan densitas rata- 


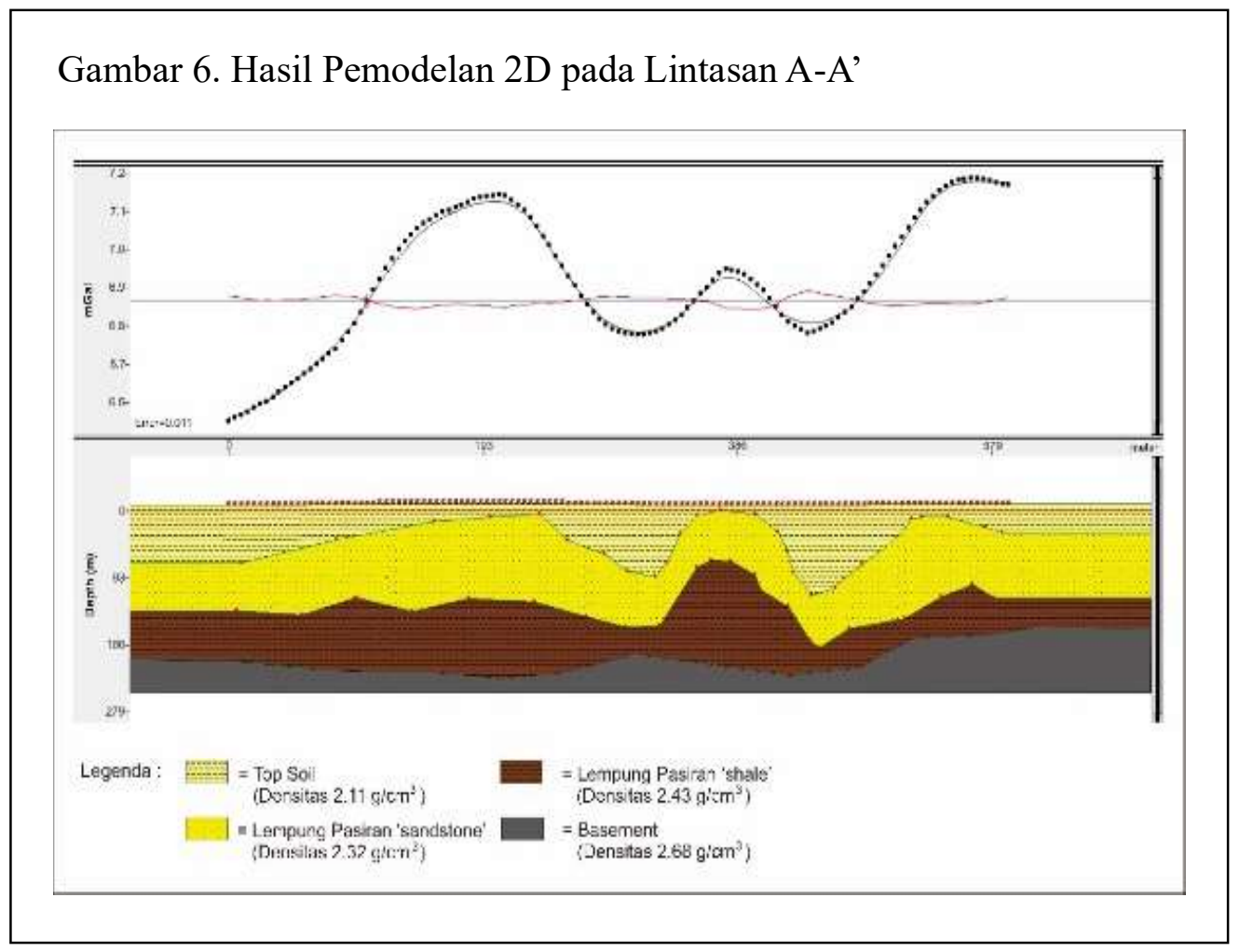

rata batuan 2,32 $\mathrm{g} / \mathrm{cm} 3$ dengan penyusun batuan didominasi batu pasir. Lapisan ketiga berada pada kedalaman 120-195 m dan densitas rata-rata batuan $2,41 \mathrm{~g} / \mathrm{cm} 3$ dengan batuan penyusunnya didominasi oleh batu serpih (shale) yang masih termasuk kedalam formasi aluvium. Gambar 7 menyajikan hasil pemodelan 2 dimensi pada lintasan B-B'.

Berdasarkan hasil pemodelan pada Gambar 7 dapat diinterpretasikan struktur bawah permukaan pada lintasan B-B' yang menunjukkan empat lapisan dengan lapisan base berada pada kedalaman lebih dari 195 $\mathrm{m}$ dan densitas rata-rata batuan $2,67 \mathrm{~g} / \mathrm{cm} 3$. Lapisan base termasuk bagian dari formasi damar (Qtd) dengan batuan penyusun berupa breksi vulkanik, konglomerat, dan tufan.
Sama seperti lintasan A-A', lapisan pertama, kedua, dan ketiga termasuk kedalam formasi aluvium (Qa). Lapisan pertama merupakan top soil yang memiliki kedalaman dari 0-50 $\mathrm{m}$ dan densitas batuan rata-rata $2,1 \mathrm{~g} / \mathrm{cm} 3$ dengan batuan penyusun berupa tanah urug, kerikil, pasir, lempung, dan sedikit lumpur. Lapisan kedua berada pada kedalaman 50$120 \mathrm{~m}$ dan densitas rata-rata batuan $2,3 \mathrm{~g} / \mathrm{cm} 3$ dengan batuan penyusun didominasi oleh batupasir (sandstone). Lapisan ketiga berada pada kedalaman 120- $195 \mathrm{~m}$ dan densitas batuan rata-rata $2,4 \mathrm{~g} / \mathrm{cm} 3$ dengan batuan penyusun didominasi oleh batuan serpih.

Pemodelan 2 dimensi ini dianggap cocok untuk mempresentasikan struktur bawah permukaan daerah penelitian yang 


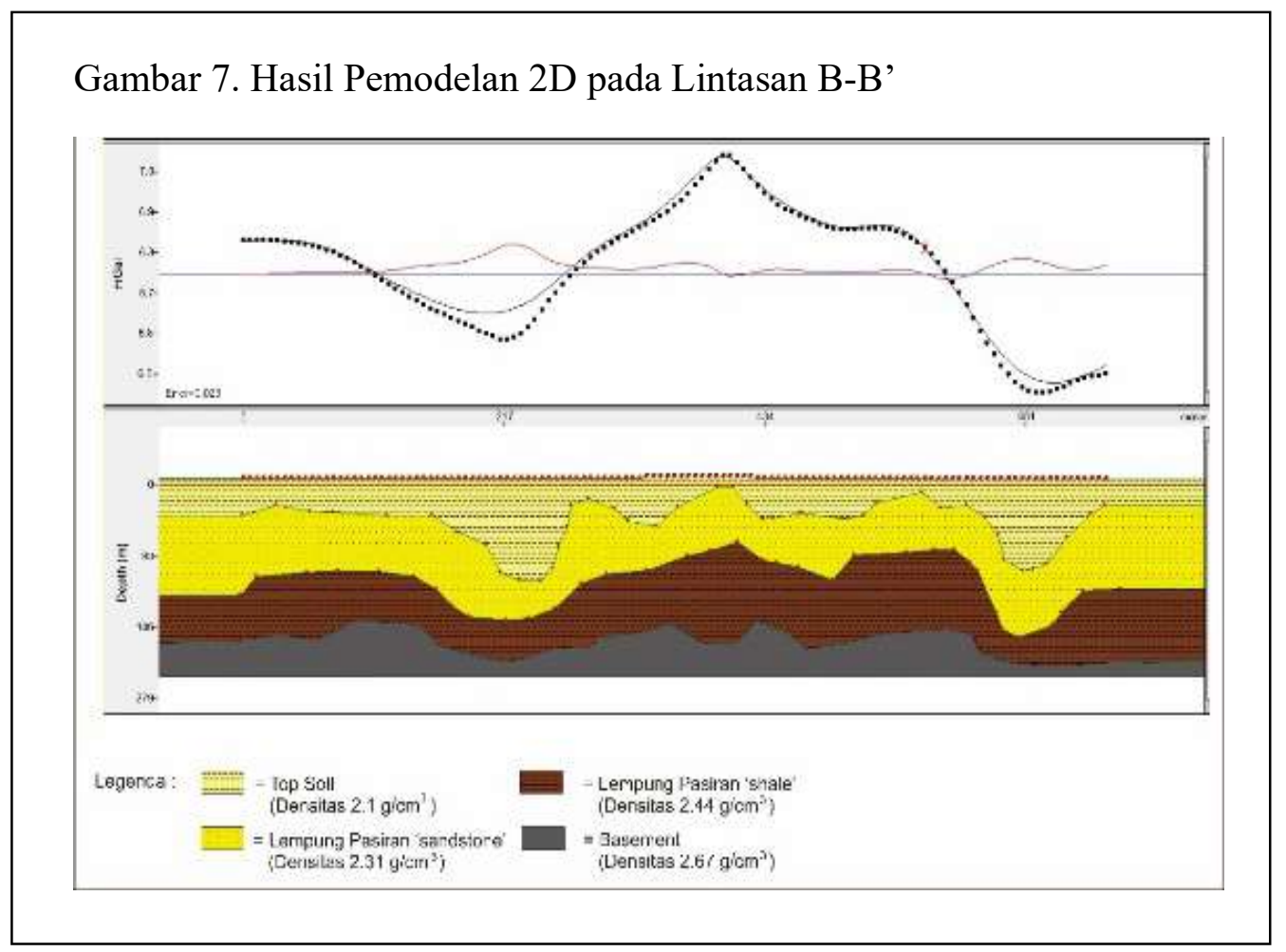

berada di Kawasan Kota Lama. Nilai densitas batuan diguanakan sebagai acuan untuk mempresentasikan struktur bawah permukaan. Nilai densitas rata-rata di daerah penelitian didapatkan dari metode parasnis. Hasil nilai densitas dari metode parasnis merupakan rata-rata densitas yang berada di seluruh titik pengukuran.

\section{SIMPULAN}

Berdasarkan hasil penelitian dan analisis data penelitian yang telah dilakukan maka dapat diambil kesimpulan sebagai berikut. Struktur bawah permukaan di kawasan Kota Lama hasil pemodelan 2 dimensi dapat diinterpretasikan dalam empat lapisan. Lapisan pertama yaitu top soil yang termasuk formasi aluvium (Qa) dengan densitas rata-rata batuan $2,1 \mathrm{~g} / \mathrm{cm}^{3}$ yang memiliki kedalaman 0-50 m. Lapisan kedua memiliki densitas rata-rata batuan 2,3 $\mathrm{g} / \mathrm{cm}^{3}$ berada di kedalaman $50-120 \mathrm{~m}$. Lapisan ketiga memiliki densitas rata-rata batuan $2,4 \mathrm{~g} / \mathrm{cm}^{3}$ berada di kedalaman 120 195 m. Penyusun batuan lapisan pertama hingga ketiga merupakan batuan sedimen seperti lempung, batu pasir, dan batu serpih. Lapisan keempat adalah base yang termasuk fornasi damar (Qtd) dengan densitas 2,67 g/ $\mathrm{cm}^{3}$ berada di kedalaman lebih dari $195 \mathrm{~m}$ dengan batuan penyusun didominasi breksi vulkanik dan tufan halus. 


\section{DAFTAR PUSTAKA}

Karunianto, A.J., Haryanto, D., Hikmatullah, F., \& Laesanpura, A. (2017). Penentuan anomali gaya berat regional dan residual menggunakan filter gaussian daerah Mamuju Sulawesi Barat. Eksplorium, 38(2), 89-98.

Purwanto, L. M. F. (2005). Kota Kolonial Lama Semarang (Tinjauan umum sejarah perkembangan arsitektur kota). DIMENSI (Journal of Architecture and Built Environment), 33(1), 27-33.

Supriyadi, Khumaedi, \& Hidayatullah, R. H. (2018). Identifikasi ketebalan lapisan sedimen dan struktur bawah permukaan di zona amblesan Kota Lama Semarang berdasarkan data mikroseismik. Spek- tra: Jurnal Fisika dan Aplikasinya, 3(3), 156-166.

Telford, W. M., Geldart, L. P., \& Sheriff, R. E. (1990). Applied geophysics (2 ${ }^{\text {nd }}$ ed.). Cambridge: Cambridge University Press.

Thanden, R. E., Sumadirdja, H., Richards, P. W., Sutisna, K., \& Amin, T. C. (1996). Peta geologi lembar Magelang dan Semarang, Jawa (ed. kedua). Bandung: Pusat Penelitian dan Pengembangan Geologi.

Wardhana, D. D., Harjono, H., \& Sudaryanto, S. (2014). Struktur bawah permukaan kota semarang berdasarkan data gaya berat. RISET Geologi dan Pertambangan, 24(1), 53-64. 